\title{
Upaya Meningkatkan Hasil Belajar Siswa melalui Penggunaan Model Pembelajaran Complete Sentence pada Mata Pelajaran Al-Qur'an Hadits Pokok Bahasan Surat At-Takatsur
}

\author{
Rida Marida \\ Institut Agama Islam Darussalam (IAID), Ciamis-Jawa Barat \\ Email: marida.rida17@gmail.com \\ Tanto Aljauharie Tantowie \\ Institut Agama Islam Darussalam (IAID), Ciamis-Jawa Barat
}

\begin{abstract}
The objectives of this study were: (1) To improve the ability of teachers in compiling lesson plans on the subject of Al-Qur'an Hadith on the subject of Surat At-Takatsur using the Complete Sentence model in class III MI Cikupa, Werasari Village, Sadananya District, Ciamis Regency; (2) To improve the teacher's ability in the process of implementing learning on the subject of Al-Qur'an Hadith, the subject of the At-Takatsur letter by using the Complete Sentence model in class III MI Cikupa, Werasari Village, Sadananya District, Ciamis Regency; (3) To improve student learning outcomes in the subject of Al-Qur'an Hadith, the subject of the At-Takatsur letter using the Complete Sentence model in class III MI Cikupa, Werasari Village, Sadananya District, Ciamis Regency. The research method used was Classroom Action Research (PTK) using the John Elliot model. This research was conducted in three cycles by carrying out several steps starting from planning, implementing, observing and reflecting. Data collection techniques used were observation, tests, interviews and descriptive analysis. The data collection instrument used was the instrument of observation of the lesson plan, the teacher's research instrument of the learning process and the instrument of student learning outcomes. After analyzing the data, the researchers obtained the following conclusions: (1) The ability of the teacher in compiling lesson plans in the Al-Qur'an Hadith subject using the Complete Sentence model increased, it was proven that in cycle I got an average score of 86.09, including the good category, in cycle II 88.13 is in the good category, and in cycle III 90.02 is in the very good category. (2) The ability of the teacher in the learning process of Al-Qur'an Hadith using the Complete Sentence model increases, it is proven that in the first cycle it gets an average score of 85.32 which is in the good category, in the second cycle 87.54 is in the good category, and in the third cycle 90 is in the good category. (3) The student learning outcomes in the Al-Qur'an Hadith subject using the Complete Sentence model increased, from the first cycle it got an average score of 70.71 including the enough category,
\end{abstract}


in the second cycle 78.33 was in the good category, and in the cycle III 87.14 is in the good category.

Keywords: Learning Outcomes, Complete Sentence Model, Al-Qur'an Hadith

\section{PENDAHULUAN}

Pendidikan agama merupakan salah satu dari tiga subyek pelajaran yang harus dimasukan dalam kurikulum setiap lembaga pendidikan formal di Indonesia. Hal ini karena kehidupan beragama merupakan salah satu dimensi kehidupan yang diharapkan dapat terwujud secara terpadu (Chabib, 1999: 1). Pendidikan Madrasah Ibtidaiyah (MI) merupakan salah satu lembaga pendidikan formal yang mewadahi siswa-siswi untuk mempelajari pendidikan agama Islam khususnya membahas Al-Qur'an Hadits untuk dipelajari siswa-siswi Madrasah Ibtidaiyah (MI). Karena Al-Qur'an dan Hadits merupakan sumber utama ajaran agama Islam, merupakan sumber akidah (keimanan), syariah, ibidah, mu'amalah dan akhlak (Muhaimin, 2008: 80).

Dengan mempelajari Al-Qur'an dan Hadits menurut M. Quraish Shihab adalah untuk membina manusia secara pribadi dan kelompok, sehingga mampu menjalankan fungsinya sebagai hamba Allah dan khalifah-Nya guna membangun dunia ini sesuai dengan konsep yang ditetapkan Allah SWT (Shihab, 2004: 179) Oleh karena itu sangat penting Al-Qur'an itu diajarkan di sekolah atau madrasah-madrasah, karena banyak hal yang bermanfaat bagi peserta didik apabila mempelajari dan diberi pendidikan tentang Al-Qur'an dan juga hadits. Mengingat kandungannya yang penuh dengan petunjuk dalam kehidupan. Sehingga dalam diri siswa akan tertanam nilai-nilai luhur dari Al-Qur'an dan juga Hadits, yang kemudian mereka jadikan sebagai pedoman hidup dan petunjuk bagi kehidupan mereka.

Al-Qur'an dan Hadits dijadikan bidang pelajaran di sekolahsekolah Islam di Indonesia, yang dikelola oleh Kementerian Agama yang membawahi sekolah-sekolah negeri maupun swasta dengan kurikulumnya yang mengembangkan Ajaran Islam. Al-Qur'an Hadits selain dipelajari pada madrasah tingkat dasar yaitu Ibtidaiyah, juga dipelajari di dua madrasah lanjutan yaitu Tsanawiyah dan Aliyah (Haward M. Federspell, 1996: 216).

Materi Al-Qur'an Hadits di Madrasah Ibtidaiyah (MI) khususnya kelas III tentang Surat At-Takatsur yang memiliki Asbabun Nuzul yaitu Surat At-Takatsur turun karena peristiwa yang terjadi di antara dua suku anshar yaitu Bani Haritsah dan Bani Al-Harits. Kedua suku itu saling bersaing memamerkan kekayaan masing-masing. Misalnya, salah seorang dari suku itu berkata pada suku yang lain, "Apa ada yang kaya raya seperti 


\section{BESTARI}

Vol. 17, No. 1, 2020

p-ISSN 1907-1337; e-ISSN 2807-6532

Pak Ahmad dari suku kami?” Kemudian suku yang lain itu membalas, misalnya begini, "Nah, tapi, apa ada yang punya rumah sebesar rumah Pak Rudi dari suku kami?” Jadi, begitulah mereka saling menyombongkan anggota suku masing-masing.

Mereka juga saling menyombongkan anggota suku mereka yang sudah meninggal. Jadi, mereka akan pergi ke kuburan. Salah satu anggota suku yang satu akan berkata, "Tapi, ada tidak yang seperti almarhum Pak Andi?” sambil menunjuk ke kuburan anggota suku mereka. Kemudian suku yang satu pun akan membalas dengan hal yang serupa. Demikianlah, mereka bersaing menyombongkan diri dengan kekayaan dan keturunnannya, baik yang masih hidup maupun yang sudah meninggal. sebagaimana yang terdapat dalam hadist yang diriwayatkan oleh Imam Muslim sebagai berikut? (Tim Diyaunnajib, 2015: 18).

Dari Abu Hurairah, ia berkata bahwa Rasulullah shallallahu 'alaihi wa sallam bersabda,

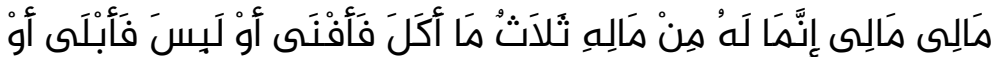

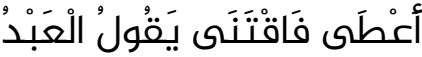

وَمَا سلِوَى ذَلِكَ فَهُوَ ذَاهِبْ وَتَاركُهُ لِلنَّاس (رواه مسلمه)

Artinya: Seorang Hamba berkata, "Harta-hartaku. Bukankah Hartanya itu hanyalah tiga: yang ia makan dan akan sirna, yang ia kenakan dan akan usang, yang ia kumpulkan. Harta selain itu akan sirna dan diberi pada orang-orang yang ia tinggalkan.” (HR.Muslim).

Manusia akan sadar dan akan teringat dari kelalaiannya saat kematian telah tiba, mereka sadar bahwa harta yang dikumpulkan selama hidupnya tidak akan dibawanya ke alam kubur. Akan tetapi, harta menjadi milik hak warisnya, selain itu, harta yang didapatkan akan menjadi masalah yang harus dipertanggungjawabkan diakhirat kelak.

Penjelasan pokok bahasan Surat At-Takatsur dapat memberikan pelajaran kepada siswa-siswi agar dapat memanfaatkan harta yang didapatkan sekecil apapun, termasuk untuk berbagai dengan sesama teman-temannya. Dengan demikian, mempelajari pokok bahasan Surat At-Takatsur menjadi sangat penting untuk dipahami sejak mereka belajar di tingkat Madrasah Ibtidaiyah (MI). Untuk mempelajari bahasan Surat At-Takatsur berhubungan dengan metode pembelajaran Al-Qur'an dan Hadits yang sudah banyak dilakukan oleh penelitian-penelitian sebelumnya di sekolah-sekolah Madrasah Ibtidaiyah (MI), seperti metode menghapal, audio-visual, ceramah dan melalui tugas-tugas.

Hasil pengamatan yang dilakukan di MI Cikupa, terlihat bahwa sebagian guru dalam proses belajar mengajar selalu menggunakan model yang kurang bervariatif sehingga kurang adanya inovasi model pembelajaran yang bisa mendukung terhadap pemahaman siswa dalam materi ini. Kemampuan siswa kelas III (Tiga) di MI Cikupa, dalam memahami materi pokok Surat At-Takatsur belum mencapai tujuan 
pembelajaran yang diharapkan. Nilai KKM pada mata pelajaran AlQur'an Hadits adalah 65. Berdasarkan data yang diperoleh sebagian besar $60 \%$ siswa yang sudah tuntas dan $40 \%$ siswa yang belum tuntas (Hasil observasi di MI Cikupa tanggal 29 Juli 2019).

Fenomena-fenomena atau gejala-gejala yang ada di MI Cikupa, terlihat bahwa hasil belajar Al-Qur'an Hadits masih tergolong rendah. Syah (1996: 129) memberikan penjelasan terkait dengan bebera faktor yang mempengaruhi belajar seseorang yaitu: Pertama, faktor internal (faktor dari dalam diri siswa) yakni keadaan/kondisi jasmanai dan rohani siswa. Kedua, faktor eksternal yakni kondisi lingkungan di sekitar siswa. Ketiga, faktor pendekatan belajar atau metode belajar yaitu terkait dengan jenis upaya belajar siswa yang meliputi strategi dan strategi yang digunakan untuk melakukan kegiatan pembelajaran materimateri pelajaran, termasuk belajar Al-Qur'an Hadits.

Metode pemebelajaran saat ini sudah mulai berkembang terutama terkait dengan model pembelajaran kooperatif. Model kooperatif dapat diterapkan untuk menjawab permasalahan yang dihadapi oleh siswa MI Cikupa. Salah satu model pembelajaran kooperatif adalah model complete sentence. Tujuannya untuk meningkatkan hasil belajar AlQur'an Hadits. Dengan model pembelajaran kooperatif tipe complete sentence diharapkan siswa lebih aktif dalam mengikuti pelajaran, sehingga hasil belajar dapat meningkat.

Model pembelajaran complete sentence memiliki kelebihan yang begitu banyak, salah satunya adalah Memperdalam dan mempertajam pengetahuan siswa melalui lembar kerja yang dibagikan, sebab mereka harus menghafal atau setidak-tidaknya memahami materi untuk bisa mengerjakan tugas menyempurnakan kalimat dengan tepat dan benar (Huda, 2014: 314).

Model complete sentence ini yang diharapkan dapat meningkatkan hasil belajar siswa dan dirumuskan dengan sebuah judul: "Upaya Meningkatkan Hasil Belajar Siswa Melalui Penggunaan Model Pembelajaran Complete Sentence pada Mata Pelajaran Al-Qur'an Hadits Pokok Bahasan Surat At-Takatsur. (Penelitian Tindakan Kelas di Kelas III MI Cikupa Desa Werasari Kecamatan Sadananya Kabupaten Ciamis)”.

\section{KAJIAN TEORETIK}

\section{Pembelajaran Al-Qur'an Hadits}

Belajar merupakan suatu proses usaha yang dilakukan seseorang untuk memperoleh suatu perubahan tingkah laku yang baru secara keseluruhan, sebagai hasil pengalaman sendiri dalam interaksi dengan lingkungannya (Slameto, 2010: 2). Menurut Hilgrad dan Bower, belajar (to learn) memiliki arti: to gain knowledge, comprehension, or mastery of trough experience or study, to fix in the mind or memory; memorize; to acquire trough experience, to become in forme of to find out. Menurut definisi tersebut, belajar memiliki pengertian memperoleh pengetahuan atau menguasai pengetahuan melalui pengalaman, 


\section{BESTARI}

Vol. 17, No. 1, 2020

p-ISSN 1907-1337; e-ISSN 2807-6532

mengingat, menguasai pengalaman, dan mendapatkan informasi atau menemukan (Baharuddin, 2010: 13).

Dari uraian di atas dapat disimpulkan bahwa belajar adalah proses seseorang dalam perubahan tingkah laku secara keseluruhan berupa adanya aktivitas atau kegiatan dan penguasaan tentang sesuatu yang bertujuan sebagai hasil pengalaman sendiri dalam interaksi dengan lingkungannya.

\section{b. Pengertian Pembelajaran}

Pembelajaran adalah suatu usaha untuk membuat peserta didik belajar atau suatu kegiatan untuk membelajarkan peserta didik. Dengan kata lain, pembelajaran merupakan suatu upaya menciptakan kondisi agar terjadi kegiatan belajar. Dalam hal ini pembelajaran diartikan juga sebagai usaha-usaha yang terencana dalam memanipulasi sumber-sumer belajar agar terjadi proses belajar dalam diri peserta didik. Menurut Warsita pengertian Pembelajaran adalah suatu usaha untuk membuat peserta didik belajar atau suatu kegiatan untuk membelajarkan peserta didik. Menurut Corey pembelajaran adalah suatu proses dimana lingkungan seseorang secara disengaja dikelola untuk memungkinkan ia turut serta dalam tingkah laku tertentu dalam kondisi-kondisi

khusus atau menghasilkan respons terhadap situasi tertentu, pembelajaran merupakan subset khusus dari pendidikan (Trianto, 2009: $85)$.

Pembelajaran merupakan terjemahan dari bahasa Inggris "instruction", terdiri dari dua kegiatan utama, yaitu: belajar (learning) dan mengajar (teaching), kemudian disatukan dalam satu aktivitas, yaitu kegiatan belajar-mengajar yang selanjutnya populer dengan istilah pembelajaran (Instruction). Pembelajaran intinya adalah "perubahan", dan perubahan tersebut diperoleh melalui aktivitas merespon terhadap lingkungan pembelajaran. Pembelajaran merupakan suatu proses usaha yang dilakukan oleh seseorang untuk memperoleh suatu perubahan yang baru sebagai hasil pengalaman dalam interaksi dengan lingkungannya untuk mencapai tujuan tertentu (Tim Pengembang MKDP, 2011: 180).

c. Pengertian Al-Qur'an Hadits

Mata pelajaran Qur'an Hadits di Madrasah Ibtida'iyah adalah salah satu mata pelajaran PAI yang menekankan pada kemampuan membaca dan menulis Al-Qur'an dan Hadits dengan benar. Selain itu juga mencangkup hafalan terhadap surat-surat pendek dalam Al-Qur'an, pengenalan arti atau makna secara sederhana dari surat-surat pendek tersebut dan hadits-hadits tentang akhlak terpuji untuk diamalkan dalam kehidupan sehari-hari melalui keteladanan dan pembiasaan (Peraturan Menteri Agama Republik Indonesia ,2008: 19). 


\section{d. Ruang Lingkup Pembelajaran Al-Qur'an Hadits}

Ruang lingkup mata pelajaran Al-Qur'an Hadits di Madrasah Ibtidai'yah (MI) meliputi:

a. Pengetahuan dasar membaca dan menulis al-Qur'an yang benar sesuai dengan kaidah ilmu tajwid.

b. Hafalan surat-surat pendek dalam Al-Qur'an dan pemahaman sederhana tentang arti dan makna kandungannya, serta pengamalannya melalui keteladanan dan pembiasaan dalam kehidupan sehari-hari.

c. Pemahaman dan pengamalan melalui keteladanan dan pembiasaan mengenai hadits-hadits yang berkaitan dengan, keutamaaan membaca Al- Qur'an, kebersihan, niat, menghormati orang tua, persaudaraan, silaturahmi, takwa, keutamaan memberi, menyayangi anak yatim, salat berjamaah, ciri-ciri orang munafik, dan amal salih (Peraturan Menteri Agama Replublik Indonesia, 2008: 23).

e. Karakteristik Mata Pelajaran Al-Qur'an Hadits di MI

Kemampuan-kemampuan dalam standar kompetensi lulusan mata pelajaran Al-qur'an dan Hadits yang harus dicapai peserta didik di tingkat Madrasah Ibtidaiyah, yaitu:

a. Membaca, menghafal, menulis dan memahami, surat-surat pendek dalam Al-Qur'an, yakni Surat Al-fatihah, An-nas sampai surat Adduha.

b. Menghafal, memahami arti, dan mengamalkan Hadits-hadiits pilihan tentang akhlak dan amal shaleh.

Kemampuan tersebut meliputi: melafalkan, membaca, menulis, menghafal, mengartikan, memahami, dan mengamalkan. Yakni dengan maksud agar peserta didik memiliki kemampuan:

a) Memahami cara melafalkan huruf-huruf hijaiyah dan tanda bacanya.

b) Menyusun kata-kata dengan huruf-huruf hijaiyah baik secara terpisah maupun bersanbung.

c) Memahami cara melafalkan dan memghafal surat-surat tertentu dalam juz' Amma.

d) Memahami arti surat tertentu dalam juz'Amma.

e) Menerapkan kaidah-kaidah ilmu tajwid dalam bacaan Al-Qur'an. Menghafal, memahami arti, dan mengamalkan Hadits tertentu tentang persaudaraan, kebersihan, niat, hormat kepada orang tua, silaturrohmi, menyayangi anak yatim, taqwa, shalat berjamaah, cirriciri orang munafiq, keutamaan memberi dan amal shaleh.

Upaya memperkenalkan Al-Qur'an dan Hadits sejak dini menjadi hal yang sangat penting. Pembelajaran Al-Qur'an dan Hadits diarahkan untuk menumbuh kembangkan pengetahuan peserta didik terhadap AlQur'an dan Hadits, sehingga memperoleh pengetahuan mengenai keduanya dengan baik dan benar.

Mata pelajaran Al-Qur'an dan Hadits di Madrasah Ibtidaiyah adalah salah satu mata pelajaran PAI yang menekankan pada kemampuan membaca dan menullis Al-Qur'an dan Hadits dengan benar, 


\section{BESTARI}

Vol. 17, No. 1, 2020

p-ISSN 1907-1337; e-ISSN 2807-6532

serta hafalan terhadap surat-surat pendek dalam Al-Qur'an, pengenalan arti atau makna secara sederhana dari surat-surat pendek tersebut dan Hadits-Hadits tentang akhlak terpuji untuk diamalkan dalam kehidupan sehari-hari melalui keteladanan dan pembiasaan.

Dengan standar kompetensi mata pelajaran Al-Qur'an Hadits ini diharapkan:

a) Peserta didik dapat mengembangkan potensi sesuai dengan kemampuan, kebutuhan dan minatnya, serta dapat menumbuhkan keimanan dan ketakwaan kepada Allah SWT, penguasaan keterampilan hidup, penguasaan kemampuan akademik, dan pengembangan kepribadaian yang paripurna.

b) Guru dapat mengembangkan kompetensi pelajaran Al-Qur'an Hadits peserta didik dengan menyediakan berbagai kegiatan pembelajaran dan sumber belajar.

c) Guru dapat menentukan bahan ajar Al-Qur'an dan Hadits sesuai dengan kondisi lingkungan sekolah dari peserta didik.

d) Orang tua dan masyarakat dapat secara aktif terlibat dalam pelaksanaan program pembelajaran Al-Qur'an dan Hadits.

Sekolah dapat menyusun program pendidikan tentang Al-Qur'an dan Hadits sesuai dengan keadaan keadaan peserta didik dan mengoptimalkan sumber belajar yang tersedia.

2. Hasil Belajar Siswa

Hasil belajar merupakan uraian untuk menjawab pertanyaan "Apa yang harus digali, dipahami, dan dikerjakan oleh siswa?” Hasil belajar ini merefleksikan keleluasaan, kedalaman, dan kompleksitas (secara bergradasi) dan digambarkan secara jelas serta dapat diukur dengan teknik-teknik penilaian tertentu. Perbedaan tentang kompetensi dan hasil belajar terdapat pada batasan dan patokan-patokan kinerja siswa yang dapat diukur (Sugandi, 2006: 63).

Hasil belajar merupakan perubahan perilaku yang diperoleh pembelajar setelah mengalami aktivitas belajar (Anni, 2006: 5). Sedangkan menurut Hamalik (1983:155) hasil belajar tampak terjadinya perubahan tingkah laku pada diri siswa yang dapat diamati, diukur dalam perubahan pengetahuan, sikap, dan keterampilan. Hasil belajar adalah kemampuan yang dimiliki oleh siswa setelah menerima pengalaman belajar (Sudjana, 2002:22). Hasil belajar merupakan perubahan tingkah laku yang baru setelah melalui proses belajar. Perolehan aspek-aspek perubahan perilaku tersebut tergantung pada apa yang dipelajari oleh pembelajar.

\section{a. Indikator Hasil Belajar}

Dalam sistem pendidikan nasional, hasil belajar dibagi menjadi tiga domain yaitu domain (ranah kognitif), domain (ranah afektif), domain (ranah psikomotor). Hal tersebut sesuai dengan pendapat Bloom (Hamzah B. Uno, 2008: 35) yang mengemukakan bahwa hasil belajar terdiri dari: 
a. Domain Kognitif

Kawasan Kognitif adalah kawasan membahas tujuan pembelajaran dengan proses mental yang berawal dari tingkat pengetahuan ketingkat yang lebih tinggi yakni evaluasi. Kawasan kognitif terdiri dari 6 tingkatan, yaitu:

1) Tingkat pengetahuan (knowledge), diartikan kemampuan seseorang dalam menghafal atau mengingat kembali atau mengulang kembali pengetahuan yang pernah diterimanya.

2) Pemahaman (comprehension), diartikan kemampuan seseorang dalam mengartikan, menafsirkan, menerjemahkan, atau menyatakan sesuatu dengan caranya sendiri tentang pengetahuan yang pernah diterimanya.

3) Tingkat penerapan (application), diartikan kemampuan seseorang dalam menggunakan pengetahuan dalam memecahkan berbagai masalah yang timbul di kehidupan sehari-hari.

4) Tingkat analisis (analysis), diartikan kemampuan menjabarkan atau menguraikan suatu konsep menjadi bagian-bagian yang lebih rinci, memilah-milih, merinci, mengaitkan hasil rinciannya.

5) Tingkat sintetis (synthetis), diartikan kemampuan menyatukan bagian-bagian secara terintegrasi menjadi suatu bentuk tertentu yang semula belum ada.

6) Tingkat evaluasi (evaluation), diartikan kemampuan membuat penilaian judgment tentang nilai (value) untuk maksud tertentu.

b. Domain Afektif

Kawasan afektif adalah satu domain yang berkaitan dengan sikap, nilai-nilai interest, apresiasi atau penghargaan dan penyesuaian perasaan sosial. Tingkatan afektif ini ada 5, yaitu: 1) Kemauan menerima, 2) Kemauan menanggapi, 3) Berkeyakinan, 4) Penerapan karya, 5) Ketekunan dan ketelitian.

c. Domain Psikomotor

Kawasan psikomotor berkaitan dengan ketrampilan atau skill yang bersikap manual atau motorik. Tingkatan psikomotor ini meliputi: 1) Persepsi, 2) Kesiapan melakukan suatu kegiatan, 3) Mekanisme, 4) Respon terbimbing, 5) Kemahiran, 6) Adaptasi, 7) Organisasi.

b. Faktor-faktor yang Mempengaruhi Hasil Belajar

Keberhasilan belajar sangat dipengaruhi oleh beberapa faktor. Faktor-faktor tersebut dapat dikelompokkan menjadi dua kelompok yaitu factor dalam diri siswa sendiri (intern) adalah Faktor dari dalam diri siswa yang berpengaruh terhadap hasil belajar di antaranya adalah kecakapan, minat, bakat, usaha motivasi, perhatian, kelemahan dan kesehatan, serta kebiasaan siswa dan faktor dari luar diri siswa (ekstern) Faktor dari luar diri siswa yang mempengaruhi hasil belajar di antaranya adalah lingkungan fisik dan nonfisik (termasuk suasana kelas dalam belajar, seperti riang gembira, menyenangkan), lingkungan sosial budaya, lingkungan keluarga, program sekolah (termasuk dukungan komite 


\section{BESTARI}

Vol. 17, No. 1, 2020

p-ISSN 1907-1337; e-ISSN 2807-6532

sekolah), guru, pelaksanaan pembelajaran, termasuk penggunaan model atau metode bervariasi dan teman sekolah (Anitah, 2008: 2.7).

2. $\quad$ Model Complete Sentence

Complete Sentence merupakan salah satu strategi pembelajaran

yang berusaha mempertimbangkan kemampusan siswa untuk memprediksi Fragmen-fragmen teks yang ditugaskan pada mereka. Complete Sentence memiliki serangkaian proses pembelajaran yang di awali dengan penyampaian materi oleh guru, analisis terhadap modul yang telah dipersiapkan, pembagian kelompok yang tidak boleh lebih dari tiga orang dengan kemampuan yang heterogen, pemberian lembar kerja yang berisi paragraf yang belum lengkap, lalu pemberian kesempatan kepada siswa untuk berdiskusi dan di akhiri dengan pengambilan kesimpulan. Dengan demikian, komponen penting dalam pembelajaran ini adalah modul, pembentukan kelompok secara heterogen yang maksimal 3 orang, diskusi, dan pengambilan kesimpulan (Huda, 2014: 313).

Model Complete Sentence merupakan rangkaian proses pembelajaran yang diawali dengan menyampaikan materi ajar oleh guru, atau dengan penganalisaan terhadap modul yang telah dipersiapkan, pembagian kelompok yang tidak lebih dari tiga orang dengan kemampuan yang heterogen, pemberian lembar kerja yang berisi paragraf yang belum lengkap, lalu diberikan kesempatan kepada siswa untuk berdiskusi dan diakhiri dengan pengambilan kesimpulan (Andayani, 2014: 212). lain:

Strategi Complete Sentence memiliki beberapa kelebihan, antara

1) Penyajian materi yang terarah dan sistematis, sebab guru terlebih dahulu menjabarkan uraian materi sebelum pembagian kelompok.

2) Melatih siswa untuk bekerja sama dan menghargai orang lain dalam berdiskusi.

3) Melatih siswa untuk berinteraksi secara baik dengan teman sekelasnya.

4) Memperdalam dan mempertajam pengetahuan siswa melalui lembar kerja yang dibagikan, sebab mereka harus menghafal atau setidaktidaknya memahami materi untuk bisa mengerjakan tugas menyempurnakan kalimat dengan tepat dan benar, dan,

5) Meningkatkan rasa tanggung jawab siswa, karena masing-masing siswa diminta tanggung jawabnya atas hasil diskusi (Huda, 2014: 314).

Kekurangan:

Akan tetapi, Complete Sentence juga memiliki kelemahankelemahan tertentu, seperti:

1) Kecendrungan hanya sebagian siswa saja yang aktif dalam diskusi.

2) Pembicaraan dalm diskusi sering kali keluar dari materi pelajaran. 
3) Perbedaan tingkat pemahaman dan penghafalan siswa atas materi pelajaran, dan ,

4) Ketidakmampuan beberapa siswa untuk menyampaikan pendapatnya dengan percaya diri dalam diskusi kelompok (Huda, 2014: 315).

Adapun langkah-langkah penerapan strategi pembelajaran Complete Sentence antara lain sebagai berikut.

1) Guru mempersiapkan lembar kerja dan modul.

2) Guru menyampaikan kompetensi yang ingin dicapai.

3) Guru menyampaikan materi secukupnya atau siswa diminta membacakan buku atau modul dengan waktu secukupnya.

4) Guru membentuk kelompok 2 atau 3 orang secara heterogen.

5) Guru membagikan lembar kerja yang berupa paragraf yang kalimatkalimat di dalamnya belum lengkap.

6) Siswa berdiskusi untuk melengkapi paragraf-paragraf tersebut dengan kunci jawaban yang tersedia.

7) Siswa berdiskusi secara berkelompok.

8) Setelah jawaban didiskusikan, jawaban yang salah diperbaiki. Tiap siswa membaca sampai mereka mengerti atau hafal.

9) Guru mengakhiri pembelajaran (Huda, 2014: 313).

\section{METODE}

Metode penelitian yang digunakan adalah metode Penelitian Tindakan Kelas (PTK) model John Elliot. Sedangkan teknik pengumpulan data yang digunakan adalah observasi, tes, wawancara dan analisis deskriptif. Teknik pengolahan data dan analisis data dalam penelitian ini adalah Seleksi data, Pengoreksian data, dan Pembobotan data. Penelitian ini bertujuan untuk meningkatkan hasil belajar siswa dengan menggunakan model pembelajaran complete sentence pada mata pelajaran Al-Qur'an Hadits pokok bahasan Surat At-Takatsur (Penelitian Tindakan Kelas di kelas III MI Cikupa Desa Werasari Kecamatan Sadananya Kabupaten Ciamis).

\section{HASIL PENELITIAN DAN PEMBAHASAN}

Dari kegiatan yang dilakukan pada Siklus 1 pertemuan 1 guru dalam menyusun Rencana Pelaksanaan Pembelajaran (RPP) di kelas kelas III MI Cikupa Desa Werasari Kecamatan Sadananya Kabupaten Ciamis memperoleh nilai rata-rata sebesar 86,09 termasuk kategori baik, sebab berada pada interval (75-90). Pada penyusunan Rencana Pelaksanaan Pembelajaran (RPP) sudah tergolong baik, walaupun masih terdapat kekurangan diantaranya kurangnya pengelolaan kelas dengan baik. Sember materi pelajaran harus lebih banyak. Evaluasi soal harus sesuai dengan model pembelajaran complete sentence. 


\section{BESTARI}

Vol. 17, No. 1, 2020

p-ISSN 1907-1337; e-ISSN 2807-6532

Pada Siklus 1 pertemuan 1 guru dalam melaksanakan proses pembelajaran di kelas III MI Cikupa Desa Werasari Kecamatan Sadananya Kabupaten Ciamis memperoleh rata-rata nilai sebesar 85,32. Termasuk kategori baik, sebab berada pada interval (75-90). Pada proses pembelajaran ini terdapat kekurangan diantaranya kurang memberikan bimbingan pada siswa. Keaktifan siswa dalam pembelajaran masih kurang. Dalam pembelajaran masih ada siswa yang tidak memperhatikan saat guru menjelaskan materi.

Hasil Belajar Siswa Siklus 1 pertemuan 1 pada mata pelajaran AlQur'an Hadits pokok bahasan Surat At-Takatsur di kelas III MI Cikupa Desa Werasari Kecamatan Sadananya Kabupaten Ciamis memperoleh rata-rata nilai yang diperoleh sebesar 70,71 termasuk kategori cukup, sebab berada pada interval (60-74). Hal ini disebabkan pada saat pembelajaran siswa masih ada siswa yang mencontek saat evaluasi pada temannya. Siswa ada yang mendapat nilai di bawah KKM dan ada siswa yang belum memahami maksud dari soal yang diberikan pada siswa.

Pada Siklus II pertemuan 2 guru (peneliti) dalam menyusun Rencana Pelaksanaan Pembelajaran (RPP) di kelas III MI Cikupa Desa Werasari Kecamatan Sadananya Kabupaten Ciamis memperoleh nilai rata-rata sebesar 88,13 termasuk kategori baik, sebab berada pada interval (75-90). Walaupun sudah tergolong baik tetap saja masih ada kekurangan yang dilakukan oleh guru (peneliti) Guru tidak memberikan petunjuk dalam pengisian soal evaluasi.

Guru (peneliti) dalam Siklus II pertemuan 2 melaksanakan proses pembelajaran di kelas III MI Cikupa Desa Werasari Kecamatan Sadananya Kabupaten Ciamis memperoleh nilai rata-rata sebesar 87,54 termasuk kategori baik, sebab berada pada interval (75-90). Walaupun sudah tergolong baik tetap saja masih ada kekurangan yang dilakukan oleh guru (peneliti) Guru tidak memberikan penghargaan/ pujian pada siswa. Banyaklah menggunakan bahasa anak, supaya siswa lebih paham.

Hasil Belajar Siswa dalam Siklus II pertemuan 2 pada mata pelajaran Al-Qur'an Hadits pokok bahasan Surat At-Takatsur di kelas III MI Cikupa Desa Werasari Kecamatan Sadananya Kabupaten Ciamis memperoleh rata-rata nilai yang diperoleh sebesar 78,33. Termasuk kategori baik, sebab berada pada interval (75-90). Pada hasil belajar siswa sudah tergolong baik dan menunjukan bahwa kemampuan siswa dalam hasil belajar mengalami peningkatan dari siklus 1 pertemuan 1.

Pada Siklus III pertemuan 3 guru (peneliti) dalam menyusun Rencana Pelaksanaan Pembelajaran (RPP) di kelas III MI Cikupa Desa Werasari Kecamatan Sadananya Kabupaten Ciamis memperoleh nilai rata-rata sebesar 90,02 termasuk kategori sangat baik, sebab berada pada interval (91-100). Semua aspek penyusunan Rencana Pelaksanaan Pembelajaran (RPP) mengalami peningkatan.

Guru (peneliti) dalam Siklus III pertemuan 3 melaksanakan proses pembelajaran di kelas III MI Cikupa Desa Werasari Kecamatan 
Sadananya Kabupaten Ciamis memperoleh nilai rata-rata sebesar 90 termasuk kategori baik, sebab berada pada interval (75-90). Pada proses pembelajaran mengalami peningkatan dan perubahan menjadi lebih baik sehingga siswa dapat mengikuti pembelajaran dengan baik.

Hasil Belajar Siswa Siklus III pertemuan 3 pada mata pelajaran Al-Qur'an Hadits pokok bahasan Surat At-Takatsur di kelas III MI Cikupa Desa Werasari Kecamatan Sadananya Kabupaten Ciamis memperoleh rata-rata nilai yang diperoleh sebesar 87,14 termasuk kategori baik, sebab berada pada interval (75-90). Hal ini terlihat dari hasil belajar siswa seluruhnya meningkat dan telah mencapai ketuntasan.

Untuk memudahkan dalam memahami hasil kinerja guru dalam menyusun Rencana Pelaksanan Pembelajaran (RPP), kinerja guru dalam melaksanakan proses pembelajaran, dan hasil belajar siswa yang sudah dilaksanakan oleh peneliti dari siklus 1 sampai dengan siklus 3 pada penelitian tindakan kelas di kelas III MI Cikupa Desa Werasari Kecamatan Sadananya Kabupaten Ciamis pada mata pelajaran mata pelajaran Al-Qur'an Hadits pokok bahasan Surat At-Takatsur

Berdasarkan data yang diperoleh dapat disimpulkan bahwa model pembelajaran complete sentence dapat meningkatkan hasil belajar siswa di kelas III MI Cikupa Desa Werasari Kecamatan Sadananya Kabupaten Ciamis pada mata pelajaran Al-Qur'an Hadits pokok bahasan surat AtTakatsur.

\section{KESIMPULAN}

Dari hasil pembahasan yang dilakukan peneliti mengenai penggunaan model complete sentence untuk meningkatkan hasil belajar siswa pada mata pelajaran Al-Qur'an Hadits pokok bahasan Surat AtTakatsur di kelas III MI Cikupa Desa Werasari Kecamatan Sadananya Kabupaten Ciamis dapat disimpulkan sebagai berikut: (1) Rencana Pelaksanaan Pembelajaran (RPP) mata pelajaran Al-Qur'an Hadits pokok bahasan Surat At-Takatsur dengan penggunaan model complete sentence di kelas III MI Cikupa Werasari Kecamatan Sadananya Kabupaten Ciamis dapat meningkatkan hasil belajar siswa. Pada siklus I mencapai nilai ratarata 86,09, siklus II nilai rata-rata 88,09, dan siklus III dengan nilai ratarata 90,02. (2) Upaya guru dalam melaksanakan pembelajaran Al-Qur'an Hadits pokok bahasan Surat At-Takatsur dengan penggunaan model complete sentence di kelas III MI Cikupa Werasari Kecamatan Sadananya Kabupaten Ciamis tahun pelajaran 2019/2020 berhasil meningkat. Pada siklus I nilai rata-rata 85,32, siklus II nilai rata-rata 87,54, dan siklus III dengan nilai rata-rata 90. (3) Hasil belajar siswa pada mata pelajaran AlQur'an Hadits pokok bahasan Surat At-Takatsur dengan menggunakan model pembelajaran complete sentence di kelas III MI Cikupa Werasari Kecamatan Sadananya Kabupaten Ciamis tahun pelajaran 2019/2020 mengalami peningkatan. Hal itu dapat dilihat dari setiap siklusnya mengalami peningkatan. Pada pembelajaran siklus I dengan rata-rata nilai 70,71 dan $57 \%$ tuntas dengan perhitungan 12 orang siswa tuntas dan 


\section{BESTARI}

Vol. 17, No. 1, 2020

p-ISSN 1907-1337; e-ISSN 2807-6532

9 orang siswa belum tuntas dari nilai ketuntasan yang ditentukan, siklus II dengan rata-rata nilai 78,33 dan $76 \%$ tuntas dengan perhitungan 16 orang siswa tuntas dan 5 orang siswa belum tuntas dari nilai ketuntasan yang ditentukan, dan siklus III dengan rata-rata nilai 87,14 dan 100\% tuntas dengan perhitungan semua orang siswa (21) telah tuntas mencapai nilai ketuntasan yang telah ditentukan.

\section{DAFTAR PUSTAKA}

Achmad Sugandi., et.al (2006). Teori Pembelajaran. Semarang: UNNES PRESS

Andayani. (2014). Pendekatacn Saintifik \& Metodologi Pembelajaran Bahasa Indonesia. Surakarta: Yuma Pustaka.

Baharuddin, (2010). Teori Belajar dan Pembelajaran. Jogjakarta: Arruz Media

Peraturan Menteri Agama Replublik Indonesia No. 2 Tahun 2008, Tentang Standar Kompetensi Lulusan dan Standar Isi Pendidikan Agama Islam dan Bahasa Arab di Madrasah.

Hamalik, Umar. (1983). Metodologi Belajar dan Kesulitan-kesulitan Belajar. Jakarta: Tarsito

Hamzah B. Uno. (2008). perencanaan pembelajaran, Bumi Aksara. Jakarta: Bumi Aksara.

Haward M. Federspell. (1996). Kajian Al-Qur'an di Indonesia, ter. Tajuk Arifin. Bandung: Mizan.

Huda, M. (2014). Model-model Pengajaran dan Pembelajaran. Yogyakarta: Pustaka Pelajar.

Muhaimin. (2008). Paradigma Pendidikan Islam: Upaya Mengefektifkan Pendidikan Agama Islam di Sekolah. Bandung: PT Remaja Rosdakarya.

M. Quraish Shihab. (2004). Membumikan Al-Qur'an: Fungsi dan Peran Wahyu dalam Kehidupan Masyarakat. Bandung: Mizan.

Slameto. (2010). Belajar dan Faktor-faktor yang Mempengaruhinya. Jakarta: PT Rineka Cipta

Sudjana, Nana. (2002). Dasar-dasar proses Belajar Mengajar. Bandung: Sinar Baru Algensindo.

Sri Anitah W. (2008). Strategi Pembelajaran SD. Universitas Terbuka, Jakarta.

Tim Diyaunnajib., et.al. (2015). Kreatif Belajar Akidah Akhlak Kelas III untuk Madrasah Ibtidaiyah: Penerbit Duta.

Tim Pengembang MKDP. (2011). Kurikulum dan Pembelajaran. Jakarta: Rajawali Pers.

Thoha, Chabib. (1999). Metodologi Pengajaran Agama. Yogyakarta: Pustaka Pelajar. 
Trianto. (2009). Mendesain Model Pembelajaran Inovatif-Progresif. Jakarta: Kencana.. 